\title{
Nursing Approach to the Control of Tuberculosis: Scientific Publications (2002-2011)
}

\author{
Brunello Maria Eugenia Firmino, \\ Magnabosco Gabriela Tavares, Arakawa Tiemi, \\ Andrade Rubia Laine de Paula and Villa Tereza Cristina Scatena
}

School of Nursing at Ribeirao Preto, University of Sao Paulo, Brazil

Received 2012-05-31, Revised 2012-06-28; Accepted 2012-06-28

\begin{abstract}
As a disease of chronic evolution, Tuberculosis (TB) requires more health care professionals, especially nursing staff, to encourage the patient not to abandon the treatment and achieve a cure. Thus, this study aimed to describe the state of the art of scientific publications regarding the approach that is given to nursing aids regarding TB control. The literature search was performed on the database of the Virtual Health Library, The Lilacs, indexed with the following descriptors: tuberculosis, nursing, nursing care, nursing services and nursing team. We established the following inclusion criteria: Papers published in Brazil between 2002 and 2011. Selected articles were separated into three categories: "daily practice of nursing care or planning for TB control", "research and teaching in nursing" and "biosafety". We selected twenty-four articles which met the criteria of the study. It was observed that there was an increase in the number of publications since 2005 , with $70.9 \%$ of articles published in specific nursing journals; $54.2 \%$ dealt with actions related to the daily practice of nursing in TB control, 37, 5\% were related to the occupational hazard caused by the direct care of patients with TB and just over $8 \%$ were related to the teaching and research of the disease for nurses. These findings highlight the interest in understanding the role of nursing care for patients with TB, raising relevant issues with respect to knowledge and skills of these professionals to fulfill their task, including concern about the risk of disease, since they are so exposed to the disease they become part of the care plan for the patient and also to the family of which this patient belongs.
\end{abstract}

Keywords: Communicable Diseases, Tuberculosis, Nursing Services, Specialties Nursing, Nursing Research, Nurse's Role, Scientific and Technical Publications

\section{INTRODUCTION}

According to the WHO (2012), Brazil is one of the 22 countries with the highest Burden of Tuberculosis (TB) in the world, occupying 20th place in this ranking. Also according to WHO documents for 2009 data, TB incidence was 43 cases/100 000 population, the mortality rate was $2.6 / 100,000$ population, with a detection rate of $88 \%$ and cure rate of $72 \%$.

Being considered a disease of chronic evolution and with a stigma and prejudice still related to TB patients, the disease requires from health services and especially from health professionals, a great responsibility towards assuring patients' adherence to treatment and not endangering their own and the populations' lives with an increasing chance of contamination between contacts (Monroe et al., 2008; Villa et al., 2008).

Faced with the complexity of the problem, nurses as well as nursing assistants become essential for patient and family encouragement in coping with the disease (Arcencio et al., 2008; Montenegro et al., 2009). The link between nursing staff and TB patient becomes as important as the drug intake, thus promoting the implementation of an individual and collective care plan, Corresponding Author: Brunello Maria Eugenia Firmino, School of Nursing at Ribeirao Preto, University of Sao Paulo, Brazil 
involving the trust that the patient and the patient's family lay in such professionals (Brunello et al., 2009).

Therefore, understanding the importance of nursing care performance for TB patients and their involvement in health services planning for efficiency in providing care, this study aimed to identify the state of art in scientific articles published over the past nine years in Brazil and which approach is given to nurses in TB control. Thus, we seek to understand the role of nursing to fight this disease, in both prevention and cure.

\section{MATERIALS AND METHODS}

State of the art consists of a bibliographical study whose main challenge maps and discusses what is being produced on some aspects and dimensions related to a thematic (Ferreira, 2002)

The scientific literature search was conducted in April 2012, in the LILACS website (http://lilacs.bvsalud.org/), the most important index of scientific and technical literature of Latin America and the Caribbean. We used the following terms indexed in the Brazilian health subject headings thesaurus (DECS-http://decs.bvs.br/I/homepagei.htm): tuberculosis, nursing, nursing care, nursing services and nursing team in the database.

We established the following inclusion criteria for the study:

- Be classified as scientific articles, thus excluding documents, manuals or thesis

- Held in Brazil

- $\quad$ Published between 2002-2011

We excluded publications classified as editorials, letters to the editor and re-publications of articles with historical analysis.

To refine the search, we opted for some combination of terms, as shown in Table $\mathbf{1 .}$

A database was built in Excel with the 55 publications. Articles that were found more than once by the combination of terms were eliminated and 24 articles remained for reading, which were classified according to the following categories:

- Year of publication

- Journal in which it was published

- Study Subject

Items categorized were:
Table 1. Number of articles found and selected for reading according to the combination of terms, Lilacs (2012)

\begin{tabular}{lcc}
\hline Combination of & $\begin{array}{c}\text { Articles } \\
\text { Found n }\end{array}$ & $\begin{array}{c}\text { Selected } \\
\text { articles n }\end{array}$ \\
Descriptors & 95 & 33 \\
Tuberculosis and nursing & 33 & 7 \\
Tuberculosis and nursing care & 16 & 7 \\
Tuberculosis and nursing services & 14 & 8 \\
Tuberculosis and nursing team & $158^{*}$ & $55^{*}$ \\
Total & \\
\hline
\end{tabular}

Table 2. Distribution of articles about tuberculosis and nursing according to the year of publication, Lilacs (2012)

\begin{tabular}{llr}
\hline Year of publication & $\mathrm{n}$ & $(\%)$ \\
\hline 2002 & 1 & 4,2 \\
2003 & 0 & 0,0 \\
2004 & 0 & 0,0 \\
2005 & 4 & 16,7 \\
2006 & 2 & 8,3 \\
2007 & 4 & 16,7 \\
2008 & 4 & 16,7 \\
2009 & 1 & 4,2 \\
2010 & 4 & 16,7 \\
2011 & 4 & 16,7 \\
Total & 24 & 100,0 \\
\hline
\end{tabular}

\subsection{Daily practice or Planning in Nursing Care for TB Control}

Articles dealing with nursing care in health services, whether hospital-based or primary care-based; directly concerned with practices carried out by nursing staff with patients for TB control whether in case identification, disease control, supervision of contacts or drug intake.

\subsection{Research and Teaching in Nursing}

Articles related to research and education for TB control involving nursing professionals or nursing students.

\subsection{Biosafety}

Articles dealing with the vulnerability of nursing professionals and students in acquiring TB infection in the workplace.

The content analysis to produce the categorization of articles was based solely on an exhaustive reading of the works selected for the study. Due to the design of the study, there was no need for authorization from the Ethics Committee of the institution.

\section{RESULTS}

The publications involving TB and nursing have been increasing since the year 2005, maintaining an average of three articles published per year in Brazil in the studied period (Table 2). 
Brunello Maria Eugenia Firmino et al. / International Journal of Research in Nursing 3 (2) (2012) 30-37

Table 3. Distribution of articles according to their title, authors, journal, study objective and object, Lilacs (2012)

\begin{tabular}{lllll}
\hline Article & Authors & Journal & Study objective & Study object \\
\hline Exploring knowledge, & Malveira & Esc Anna Nery & To discuss knowledge, & Research and teaching \\
practices and attitudes & et al. $(2002)$ & Rev Enferm & attitudes and practices \\
of undergraduate nursing & & & $\begin{array}{l}\text { regarding prevention of } \\
\text { nosocomial transmission of }\end{array}$ & in nursing \\
students of a governmental & & & tubect, Lilacs (2012)
\end{tabular}

university concerning the

prevention of tuberculosis

dissemination

Active search for individuals

with respiratory symptoms as

part of community health workers'

role in tuberculosis control

Nursing workers' experiences in care for pulmonary

tuberculosis patients

Epidemiological profile of outpatients with HIV/AIDS at a school hospital:

São Paulo city

Prevalence and incidence of Mycobacterium tuberculosis infection in nursing students in Vitória, Espírito Santo

Practical tuberculosis teaching in nursing schools, Brazil û 2004 The nursing team's knowledge of care for patients suspected of having or diagnosed with pulmonary tuberculosis: An exploratory study

Peculiarities of tuberculosis control in a scenario of urban violence in a disadvantaged community in Rio de

Janeiro, Brazil The vulnerability of nursing workers to tuberculosis in a teaching hospital

Nosocomial Mycobacterium tuberculosis transmission among healthcare students in a high incidence region, in Vitória, State

of Espírito Santo
Muniz et al. Cienc.

To analyze the incorporation of

Bertazone Rev Lat Am

et al. (2005) Enfermagem

tuberculosis among nursing

students of the last

period of graduation.

To analyze the incorporation of Daily practice or planning

Gabriel et al. Rev Lat Am

(2005) Enfermagem

Maciel Rev Soc Bras Evaluated the incidence

et al. (2010) Med Trop of Mycobacterium tuberculosis

Villa Online Bras

et al. (2006) J. Nurs

Avelar Online Bras

et al. (2006) J. Nurs

Souza J. Bras

et al. (2007) Pneumol

Souza and

Rev. Lat. Am.

Bertolozzi Enfermagem

(2007)

Maciel

Rev. Soc. Bras

et al. (2010) Med. Trop the active search for respiratory

symptoms for Tuberculosis Control

at a Municipal Health District in

Ribeirão Preto-SP, Brazil,

according to the perception of

nursing supervisors in the

Community Health

Agent Program (CHAP).

To identify the positive and negative

aspects related to nursing

care for pulmonary

tuberculosis patients,

based on the reports of nursing

workers at an isolation unit.

To characterize the epidemiological

profile of patients with HIV/AIDS

at an outpatient service, to analyze

the infection stage on the patient's

first return, lethality

and program evasion

infection among nursing

students at the Federal University

of Espírito Santo, using the

purified protein derivative test.

To analyze practical tuberculosis

TB) teaching in Nursing Schools

((NS) in Brazil in 2004.

To identify the knowledge of nursing

team members of protective measures

to be deployed in caring for

adult patients suspected of having

or diagnosed with pulmonary tuberculosis, confined in clinical-surgical and emergency units of a university hospital

To describe the difficulties and peculiarities encountered by health professionals during the treatment and investigation of contacts of tuberculosis (TB) patients in

disadvantaged communities.

in nursing care

for TB control

Daily practice or planning in nursing care for TB control

Daily practice or planning in nursing care for TB control

Biosafety

To identify aspects that potentially

increase the vulnerability of nursing

workers to tuberculosis, through

the verification of personal life,

work and disease

knowledge indexes.

To evaluate hypersensitivity to

tuberculin among medical students
Daily practice or planning in nursing care for TB control

Biosafety

Research and Teaching

in Nursing

Biosafety 
Brunello Maria Eugenia Firmino et al. / International Journal of Research in Nursing 3 (2) (2012) 30-37

Table 3. Continue

\begin{tabular}{|c|c|c|c|}
\hline $\begin{array}{l}\text { Tuberculin skin test } \\
\text { applied to nursing students }\end{array}$ & $\begin{array}{l}\text { Moreira } \\
\text { et al. (2007) }\end{array}$ & $\begin{array}{l}\text { Rev. Enferm. } \\
\text { UERJ }\end{array}$ & $\begin{array}{l}\text { To quantify the prevalence of positive } \\
\text { Tuberculin Skin Test (TST) among } \\
\text { nursing students from the Federal }\end{array}$ \\
\hline
\end{tabular}

Bibliographic production about adherence/nonadherence to therapy

Epidemiological profile of tuberculosis cases reported among health care workers at the University Hospital in Vitoria, Brazil

Tuberculosis in nursing personnel: A population based epidemiological approach

The expansion of the treatment observed (TS) for the control of tuberculosis in Paraiba (2000/2005)

Prevalence of tuberculosis infection in students at the State University in Montes Claros, Minas Gerais, Brazil

Multiculturality and morbidity related by Bolivian immigrants in the Family Health Strategy

The Active Search for Respiratory

Symptomatics for the Control of Tuberculosis in the Potiguara Indigenous

Scenario, Paraiba, Brazil

Accessibility: hindrances to decentralization of tuberculosis control in units of family health
Reiners

Cienc. To analyze the Latin American

University of Goiás û UFG, in Goiania,

et al. $(2008)$

GO, Brazil, in September, 2006.
To analyze the Latin American

the last 10 years regarding the

adherence / non-adherence to treatment

of people with chronic health

problems: leprosy, tuberculosis,

hypertension, diabetes and AIDS.

Prado J Bras. To describe the epidemiological

et al. (2008) Pneumol. profile of tuberculosis cases reported

among health care workers in

the Tuberculosis Control Program

of the Cassiano Antonio of Moraes

University Hospital in Vitoria, Brazil.

Lorenzi and Rev. Bras To present the incidence of tuberculosis

Oliveira (2008)

saúde ocup all forms) among nursing

workers in São Paulo, comparing

(it with the general population in year 2004 estimate your risk of TB disease, to describe notified according to the individual workplace (type of work where EAS) discuss the implications and the possible consequences of actions articulated surveillance in the presence

of NR-32, compared to aspectsepidemiology of this injury.

Rodrigues Rev. Eletrônica To analyze the strengths and

et al. (2008) Enferm weaknesses in the expansion process of the supervised treatment in six cities considered as priorities for the TB control in Paraíba-PB/Brazil.

Coelho Rev. Bras. To identify the tuberculosis infection et al. (2009) Edu. Med. rate among students from the first and last two years in the Schools of Medicine and Nursing at the State University in Montes Claros, Minas Gerais, Brazil, in addition to verifying their knowledge on transmission and prevention of occupational tuberculosis and the use of the recommended preventive measures.

Melo and Mundo To identify the more frequently

Campinas Saúde reported morbidity by Bolivian

(2010) immigrants who are users of a USF (Family Health Unit) of São Paulo city

Nobrega Rev Lat Am To analyze the actions of an active

et al. (2010) Enfermagem search for Respiratory Symptomatic

(RSs) in the control of Tuberculosis

(TB) in the Potiguara Special Indigenous Sanitary District,

Paraiba, Brazil, between

May and June 2007.

Clementino Rev. To analyze social representations of

and Enferm

Miranda UERJ

(2010) tuberculosis by users of family

health units in Campina Grande,

$\mathrm{PB}$, Brazil, in view of

decentralization of disease control.
Daily practice or planning in nursing care for TB control

Biosafety

Biosafety

Daily practice or planning in nursing care for TB control

Biosafety

Daily practice or planning in nursing care for TB control

Daily practice or planning in nursing care for TB control

Daily practice or planning in nursing care for TB control 
Table 3. Continue

\begin{tabular}{|c|c|c|c|c|}
\hline $\begin{array}{l}\text { Household members and health } \\
\text { care workers as supervisors } \\
\text { of tuberculosis treatment. }\end{array}$ & $\begin{array}{l}\text { Maciel } \\
\text { et al. }(2010)\end{array}$ & $\begin{array}{l}\text { Rev. Saude } \\
\text { Publica/ } \\
\text { Salud Publica }\end{array}$ & $\begin{array}{l}\text { To compare tuberculosis cure rates } \\
\text { among patients supervised by } \\
\text { household members } \\
\text { or health care workers. }\end{array}$ & $\begin{array}{l}\text { Daily practice or planning } \\
\text { in nursing care for TB control }\end{array}$ \\
\hline $\begin{array}{l}\text { Tuberculin skin test: operational } \\
\text { research in the state of } \\
\text { Mato Grosso do Sul, Brazil }\end{array}$ & $\begin{array}{l}\text { Oliveira } \\
\text { et al. (2009) }\end{array}$ & $\begin{array}{l}\text { J. Bras } \\
\text { Pneumol }\end{array}$ & $\begin{array}{l}\text { To investigate operational } \\
\text { aspects of Tuberculin } \\
\text { Skin Test (TST) use in } \\
\text { tuberculosis control programs } \\
\text { and at specialized Brazilian } \\
\text { National Sexually Transmitted } \\
\text { Diseases/AIDS and Viral Hepatitis } \\
\text { Program health care clinics } \\
\text { in priority municipalities for } \\
\text { tuberculosis control in } \\
\text { the state of Mato Grosso } \\
\text { do Sul, Brazil. }\end{array}$ & $\begin{array}{l}\text { Daily practice or planning } \\
\text { in nursing care for } \mathrm{TB} \text { control }\end{array}$ \\
\hline $\begin{array}{l}\text { Prevalence of tuberculosis } \\
\text { infection in employees } \\
\text { from university hospital }\end{array}$ & $\begin{array}{l}\text { Sousa } \\
\text { et al. }(2011)\end{array}$ & $\begin{array}{l}\text { Rev. } \\
\text { Para. Med. }\end{array}$ & $\begin{array}{l}\text { To describe the prevalence } \\
\text { of tuberculosis infection in } \\
\text { employees of the sectors of } \\
\text { the internal medicine, Infectum } \\
\text {-Parasitic Diseases (IPD) and } \\
\text { pneumology of the University } \\
\text { Hospital João de Barros } \\
\text { Barreto (UHJBB) by TST }\end{array}$ & \\
\hline $\begin{array}{l}\text { Assessment of a clinical } \\
\text { score for screening } \\
\text { suspected pulmonary } \\
\text { tuberculosis case }\end{array}$ & $\begin{array}{l}\text { Castro } \\
\text { et al. }(2011)\end{array}$ & $\begin{array}{l}\text { Rev. Saude } \\
\text { Publica/ } \\
\text { Salud Publica }\end{array}$ & $\begin{array}{l}\text { To assess the accuracy } \\
\text { (sensitivity) of a clinical score } \\
\text { for presumptive pulmonary } \\
\text { tuberculosis cases } \\
\text { during screening. }\end{array}$ & $\begin{array}{l}\text { Daily practice or planning } \\
\text { in nursing care for } \mathrm{TB} \text { control }\end{array}$ \\
\hline $\begin{array}{l}\text { Alcohol use during } \\
\text { tuberculosis treatment: } \\
\text { Patients' perception }\end{array}$ & $\begin{array}{l}\text { Silva } \\
\text { et al. }(2011)\end{array}$ & $\begin{array}{l}\text { SMAD Rev } \\
\text { eletrônica } \\
\text { Saúde } \\
\text { Mental } \\
\text { alcool drog }\end{array}$ & $\begin{array}{l}\text { To describe and analyze the } \\
\text { perception of alcohol use during TB } \\
\text { treatment and discuss the } \\
\text { interventions by the health } \\
\text { and nursing team. }\end{array}$ & $\begin{array}{l}\text { Daily practice or } \\
\text { planning in nursing } \\
\text { care for TB control }\end{array}$ \\
\hline
\end{tabular}

Of the 24 articles selected for analysis in this study, $70.9 \%$ were published in journals in the area of nursing (41.7\%), public health (16.7\%) and pulmonology (12.5\%). The remaining articles $(29.1 \%)$ were published in journals covering various themes, from medicine in general to occupational and mental health (Table 3).

Regarding to the study objective, most articles (54.2\%) approached nursing actions for TB control and daily practice and planning in nursing care, which involves the day-to-day assistance for TB patients and their families in health services, from diagnosis through to treatment. Other articles (37.5\%) addressed the concern with the occupational health of nursing professionals and students related to TB infection when exposed to the patients, showing the concern with the biosafety of these professionals (Table 3). The theme of teaching and research in nursing was the least discussed (8.3\%) among the studies analyzed, showing that this objective is still rarely covered in research conducted in Brazil. It is noteworthy that in $58.3 \%$ of the papers, nursing was not even mentioned in the title, nor in the study objective, showing that in most studies, nursing is discussed throughout the text by mentioning practical aspects of nursing care for TB patients and families.

\section{DISCUSSION}

The link between nursing practice and control of TB has a long history relating to the policies of disease control in Brazil (Baptista et al., 2006; Almeida-Filho et al., 2009), where nurses have autonomy in test ordering and also in starting treatment to fight the illness.

In 1998, Directly Observed Therapy (DOT) began to be implemented in Brazil in order to reduce drop-out of the treatment, improve cure rates and increase case identification (BMH, 2002). Thus, this may explain the number of articles published over the past nine years. The nursing staff became one of the main links between patient and health service, acting directly for adherence to treatment (Brunello et al., 2009), which may also suggest that the increase in studies related to the theme could be an attempt to evaluate and analyze the new policies established in Brazil after DOT. 
Once it had become a field of interest to nursing practices in health services, because the nurse and nursing staff in most cases are primarily responsible for TB case monitoring and supervision of drugs intake (Gabriel et al., 2005; Reiners et al., 2008), we noted that most of the articles were published in journals specific to the nursing area, followed by journals in public health, justified by social and living determinants of TB (Brunello et al., 2011; Vendramini et al., 2006; 2010).

The categorization of articles reflects the responsibilities involving the care provided to patients with TB case detection, through daily practice of nursing in health services and care planning for TB assistance. Studies selected for analysis in this study showed that nursing staff need to have innovative and efficient tools for patients and their families for early diagnosis (Castro et al., 2011; Silva at al., 2011), as well as effective strategies for monitoring TB treatment (Maciel et al., 2010; Rodrigues et al., 2008).

As well as addressing the day-to-day practices of direct nursing care to patients, families and vulnerable groups, we highlight the need for nurses in previous care planning, identifying the vulnerable groups for TB disease within the community and then perform active case identification (Souza et al., 2007; Melo and Campinas, 2010; Nobrega et al., 2010), to increase case detection rates among the population.

Another aspect raised among the studies analyzed, was the training of nursing professionals to promote awareness of TB transmission and prevention, in addition to the organizational problems of health services with human resources. We also identified discussions about addressing active case identification in the community and strengthening professional-patient interaction in areas of high health care professional turnover (Muniz et al., 2005; Bertazone et al., 2005; Rodrigues et al., 2008; Clementino and Miranda, 2010).

A significant portion of the selected studies showed the fear of scholars with the possibility of nursing students and professionals in acquiring TB during their profession (Avelar et al., 2006; Souza and Bertolozzi, 2007; Prado et al., 2008; Coelho et al., 2009; Sousa et al., 2011). Thus, discussions about the occupational risk of developing active $\mathrm{TB}$ is a frequent concern, raising questions about time of exposure and contact with TB patients, tuberculin skin testing among nursing students (Moreira et al., 2007), as well as the use of safety equipment (Lorenzi and Oliveira, 2008). Additionally, a study conducted in Brazil in 2008 (Lorenzi and Oliveira
2008) outlined some indicators concluding that the risk of developing active TB is higher among nurses, because they are in longer contact with patients.

The worksheet offered on TB for nurses' formation (Villa et al., 2006) and nursing students' knowledge of TB (Malveira et al., 2002) was the approach found in two articles selected for the study. We can see the concern with the wrong knowledge about TB transmission that nursing students still have, as well as the little time that is dedicated to teaching and practice in the area. This shows a deficit in health education and prevention of this disease among future health professionals, leading to barriers in identifying cases, since some students leave education unprepared to take over the management of similar TB cases (Malveira et al., 2002; Villa et al., 2006).

Though only two articles with a teaching and research approach were selected, according to Villa (2008), nursing has contributed significantly to research in the TB field, especially in operational studies, which allows the generation of new knowledge of the social and political determinants surrounding the disease.

It shows superficiality in the studies as regards to the control of TB, since research abides to more technical knowledge aspects in the field of nursing, which may explain the low number of outputs connected to TB research and teaching as well, with little or no involvement of nursing in the political and managerial programs of disease control in Brazil.

\section{CONCLUSION}

The results of this study indicate that there is a greater concern about the practices and performance of nursing professionals who deal directly with TB patients in health services, showing that nursing is recognized as an important element in disease control. Therefore, the planning of care from detection to treatment of the case is most often up to the professionals.

The selected articles show the interest in understanding the role of nursing care for TB patients, raising relevant issues of professionals' knowledge and skills to fulfill their task and includes concern about infection risks, since the professionals are so exposed to Mycobacterium tuberculosis that they are actually part of the care plan to which the patient belongs.

Thus, it is essential for the continued interest of scholars, in the context of nursing professionals and in addressing more often the issues facing the teaching and research of TB in nursing training, practice and research. 


\section{ACKNOWLEDGEMENT}

Foundation for research in the state of Sao Paulo (FAPESP)-doctorate, process number: 2010/51209-9 and Operational Studies Group of the Brazilian Tuberculosis Research.

\section{REFERENCES}

Almeida-Filho, A.J., H.R.A. Montenegro and T.C.F. Santos, 2009. A new strategy in the combat of tuberculosis in Brazil: Implications for nursing practice. Rev. RENE, 10: 114-123.

Arcencio, R.A., M.F. Oliveira, R.I. Cardozo-Gonzales, A. Ruffino-Netto and I.C. Pinto et al., 2008. City tuberculosis control coordinators' perspectives of patient adherence to DOT in Sao Paulo State, Brazil, 2005. Int. J. Tuberc Lung Dis., 12: 527-531.

Avelar, M.D.C.Q., T.A.C.D. Paula, M.I. Shimizu, M.A.D. Neves and C.E. Petrizzo, 2006. The nursing team's knowledge of care for patients suspected of having or diagnosed with pulmonary tuberculosis-an exploratory study. Online Braz. J. Nurs.

Baptista, S.S., A.J.A. Filho and G.T. Lopes, 2006. Nurse's preoccupying situation on tuberculosis disease. Esc. Anna Nery Rev. Enferm, 10: 15-17.

Bertazone, E.C., E. Gir and M. Hayashida, 2005. Nursing workers' experiences in care for pulmonary tuberculosis patients. Rev Lat. Am. Enfermagem, 13: 374-381.

BMH, 2002. TB Control: A proposal to integrate education-service. Brazil Ministry of Health.

Brunello, M.E.F., D.F. Cerqueira, I.C. Pinto, R.A. Arcencio and R.I.C. Gonzales et al., 2009. Vínculo persona enferma-profesional de salud en la atencion a pacientes con tuberculosis. Acta Paul. Enferm., 22: 176-182. DOI: 10.1590/S0103-21002009000200010

Brunello, M.E.F., F.C. Neto, R.A. Arcencio, R.L.D.P. Magnabosco and G.T. Magnabosco et al., 2011. Areas of vulnerability to HIV/TB co-infection in southeastern Brazil. Rev. Saude Publica., 45: 556563. DOI: 10.1590/S0034-89102011005000018

Castro, C.B.A.D., P.A.D. Costa, A. Ruffino-Netto, E.L.N. Maciel and A.L. Kritski, 2011. Assessment of a clinical score for screening suspected pulmonary tuberculosis cases. Rev. Saude Publica., 45: 1110-1116. DOI: 10.1590/S0034-89102011005000071

Clementino, F.D.S. and F.A.N.D. Miranda, 2010. Accessibility: hindrances to decentralization of tuberculosis control in units of family health. Rev. Enferm. UERJ, 18: 584-590.
Coelho, M.A.D.Q., C.R. Biscotto, B.R. Tinois, F.C. Freitas and J.S. Oliveira et al., 2009. Prevalence of tuberculosis infection in students at the State University in Montes Claros, Minas Gerais, Brazil. Rev. Bras. Educ. Med., 33: 535-541.

Ferreira, N.S.A., 2002. Research called state of art. Educ. Soc., 23: 257-272.

Gabriel, R., D.A. Barbosa and L.A.C. Vianna, 2005. Perfil epidemiologico dos clientes com hiv/aids da unidade ambulatorial de hospital escola de grande porte-municipio de sao paulo. Rev. Lat. Am. Enfermagem, 13: 509-513.

Lilacs, 2012. Literature in heath sciences from latino america and caribbe.

Lorenzi, R.L. and I.M.D. Oliveira, 2008. Tuberculose em trabalhadores de Enfermagem: Uma abordagem epidemiologica de base populacional. Rev. Bras. Saude Ocup., 33: 6-14.

Maciel, E.L.N., L.M. Guidoni, A.P. Brioshi, T.N.D. Prado and G. Fregona et al., 2010. Household members and health care workers as supervisors of tuberculosis treatment. Rev. Saude Publica, 44: 339343.

Malveira, E.A.P., R.H. Griep and C.F. Cardoso, 2002. Exploring knowledges, practices and attitudes of undergraduated nursing students of a governamental university concerning the prevention of tuberculosis dissemination. Esc. Anna Nery Rev. Enferm., 6: 273-283.

Melo, R.A.D. and L.D.L.S.L. Campinas, 2010. Multiculturality and morbidity related by bolivian immigrants in the Family Health Strategy. Mundo Saude, 34: 25-35.

Monroe, A.A., R.I. Cardozo-Gonzales, P.F. Palha, C.M. Sassaki and A. Ruffino-Netto et al., 2008. Involviment of health primary care teams in the control of tuberculosis. Rev. Esc. Enferm. USP., 42: 262-267.

Montenegro, H.R., A.J.D. Almeida-Filho, T.C. Santos and L.H. Lourenco, 2009. The registered nurse and the battle against tuberculosis in Brazil: 1961-1966. Rev Esc Enferm USP., 43: 945-952. PMID: 20085168

Moreira, M.A.C., R.G. Napole and V.N. Silva, 2007. Tuberculin skin test applied to nursing students. Rev. Enferm. UERJ, 15: 387-392.

Muniz, J.N., P.F. Palha, A.A. Monroe, R.I.C. Gonzales and A.R. Netto et al., 2005. Active search for individuals with respiratory symptoms as part of community health workers' role in tuberculosis control. Cienc. Saude Coletiva, 10: 315-321. 
Nobrega, R.G., J.A. Nogueira, A.R. Netto, L.D.D. Sa and A.T.D. Silva et al., 2010. The active search for respiratory symptomatics for the control of tuberculosis in the potiguara indigenous scenario. Paraiba, Brazil. Rev. Lat. Am. Enfermagem, 18: 1169-1176. PMID: 21340283

Oliveira, H.M.M.G., R.C. Brito, A.L. Kritski and A. Ruffino-Netto, 2009. Perfil epidemiologico de pacientes portadores de TB internados em um hospital de referencia na cidade do Rio de Janeiro. J. Bras. Pneumol. DOI: 10.1590/S180637132009000800010

Prado, T.N.D., H.S. Galavote, A.P. Brioshi, T. Lacerda and G. Fregona et al., 2008. Epidemiological profile of tuberculosis cases reported among health care workers at the university hospital in Vitoria, Brazil. J. Bras. Pneumol., 34: 607-613.

Reiners, A.A.O., R.C.D.S. Azevedo, M.A. Vieira and A.L.G.D. Arruda, 2008. Bibliographic production about adherence/non-adherence to therapy. Cienc. Saude Coletiva, 13: 2299-2306.

Rodrigues, G.D.O., L.D.D. Sa, J.D.A. Nogueira, L.C.L. Damascena and A.L.C. Gomes et al., 2008. The expansion of the Treatment observed (TS) for the control of tuberculosis in Paraiba (2000/2005). Rev. Eletr. Enf., 10: 632-642.

Silva, C.B.D., R.D.S. Lafaiete and M. Donato, 2011. Alcohol use during tuberculosis treatment: Patients' perception. SMAD, Rev. Eletr. Saude Mental Alcool. Drog, 7: 10-17.

Sousa, B.A.D., V.H.C. Braz and A.L.V. Paes, 2011. Prevalence of tuberculosis infection in employees from university hospital. Rev. Para. Med.

Souza, J.N.D. and M.R. Bertolozzi, 2007. The vulnerability of nursing workers to tuberculosis in a teaching hospital. Rev. Lat. Am. Enfermagem, 15: 259-266.
Souza, F.B.A.D., T.C.S. Villa, S.C. Cavalcante, A.R. Netto and L.B. Lopes et al., 2007. Peculiarities of tuberculosis control in a scenario of urban violence in a disadvantaged community in Rio de Janeiro, Brazil. J. Bras. Pneumol., 33: 318-322.

Vendramini, S.H., M.L. Santos, C.E. Gazetta, F. Chiaravalloti-Neto and A. Ruffino-Netto et al., 2006. Tuberculosis risks and socio-economic level: A case study of a city in the Brazilian south-east, 1998-2004. Int. J. Tuberc Lung. Dis., 10: 12311235. PMID: 17131781

Vendramini, S.H., N.S. Santos, M.L. Santos, F. Chiaravalloti-Neto and M.A. Ponce et al., 2010. Spatial analysis of tuberculosis/HIV coinfection: Its relation with socioeconomic levels in a city in southeastern Brazil. Rev. Soc. Bras. Med. Trop., 43: 536541. PMID: 21085865

Villa, T.C., 2008. Nursing knowledge production in tuberculosis control in Brazil. Rev. Lat Am. Enfermagem, 16: 653-658. PMID: 18833444

Villa, T.C.S., D.R. Firmino, M.E.F. Brunello, M.F. Oliveira and A.R. Netto, 2006. Practical tuberculosis teaching in nursing schools, A survey. Online Braz. J. Nurs.

Villa, T.C.S., M.E.F. Brunello, R.A. Arcencio, C.M. Sassaki and E.G. Assis et al., 2008. Factors predicting unfavorable results in tuberculosis treatment: An integrative literature review (20012005). Online Braz. J. Nurs.

WHO, 2012. Tuberculosis country profiles. World Health Organization. 